\title{
Foraging habitat and diving activity of lactating Subantarctic fur seals in relation to sea-surface temperatures at Amsterdam Island
}

\author{
Jean-Yves Georges ${ }^{1,2}$, Francesco Bonadonna ${ }^{1,3}$, Christophe Guinet $^{1, *}$ \\ 'Centre d'Etudes Biologiques de Chizé, Centre National de la Recherche Scientifique, UPR 1934, 79360 Villiers en bois, France \\ ${ }^{2}$ Laboratoire de Biochimie et Biologie Marines, Université de La Rochelle, EA 1220, 17042 La Rochelle, France \\ ${ }^{3}$ Dipartimento di Etologia, Ecologia ed Evoluzione, Università di Pisa, Via Volta 6, 56126 Pisa, Italy
}

\begin{abstract}
This study investigates the foraging behaviour of lactating Subantarctic fur seals Arctocephalus tropicalis breeding on Amsterdam Island, Indian Ocean, in relation to sea-surface temperatures (SST) of the surrounding waters over 3 consecutive breeding years (1995 to 1997). Foraging habitat and diving activity were investigated using time depth temperature recorders (TDRs), deployed on 29 individuals during the first trip after parturition in December $(n=7)$, later in the summer $(n=13)$, and in winter $(n=9)$. Argos satellite transmitters $(n=4)$ and a direction recorder $(n=1)$ were also used in the 1995 and 1996 austral summers, respectively. Sea temperatures recorded by TDRs in conjunction with the IGOSS SST database were used as a locational cue to estimate the foraging range. The foraging habitat of lactating females was associated with the northern part of the Subtropical Front (STF) (axial SST $=14.2^{\circ} \mathrm{C}$ ), where their main prey, myctophid fish, are known to be abundant. The organisation of the foraging trips, in terms of diving activity, showed seasonal changes but remained similar among years. During the first trip after parturition, females foraged within the STF, 60 to $130 \mathrm{~km}$ from the colony, and exhibited a diving activity that did not vary significantly throughout the trip. Later in summer, when STF was south of Amsterdam Island, most females travelled in a straight south-east direction without diving (suggesting that they travelled regularly to reach a known area). They then concentrated their diving activity in the middle of the STF during $50 \%$ of the foraging trip duration, and continued diving on the return trip to the colony. In winter, the $14^{\circ} \mathrm{C}$ surface isotherm was $250 \mathrm{~km}$ north of Amsterdam Island and SST gradient was very low. Females increased their foraging range up to $530 \mathrm{~km}$, and there was no evidence for females concentrating their diving activity within a given area, suggesting that they did not encounter dense patches of prey. In winter, seals also increased their diving effort probably in response to a decrease in food availability. Annual changes in SST surrounding Amsterdam Island, and in the surface temperature gradient of the STF appear to affect the time spent at sea, and the relative diving activity throughout the trips in summer. These results suggest that Subantarctic fur seals adjust their foraging behaviour according to both seasonal and annual changes in oceanographic conditions, and thus probably, food availability.
\end{abstract}

KEY WORDS: Amsterdam Island - Arctocephalus tropicalis - Biotelemetry · Foraging - Sea-surface temperatures $\cdot$ Southern Indian ocean · Subantarctic fur seals · Subtropical Front

\section{INTRODUCTION}

The marine environment is characterised by a spatio-temporal heterogeneity of physical parameters such as sea temperature and salinity, resulting in frontal systems, eddies, upwelling zones, warm cores,

•E-mail: guinet@cebc.cnrs.fr and thermoclines. Such discontinuities are generally defined by a sharp change in the above-cited parameters, marking physical and chemical boundaries between different water masses, and correspond to biogeographical transition zones (Mann \& Lazier 1991). Frontal structures are generally associated with enhanced biological activity, with high phyto- and zooplanktonic biomass and production in comparison to 
adjacent waters (Lutjeharms et al. 1985, Mann \& Lazier 1991, Laubscher et al. 1993). Thus spatial heterogeneity of physical parameters induces heterogeneity in the distribution of marine resources (Hunt \& Schneider 1987, Koubbi 1993). Ultimately, marine predator distribution, abundance, and behaviour are related to the oceanographic factors and productivity (Jaquet \& Whitehead 1996) that determine prey distribution, as shown in seabirds (Weimerskirch et al. 1994, 1997. Bost et al. 1997. Guinet et al. 1997), and marine mammals (e.g. whales: Machida 1974, Tynan 1998; southern elephant seals Mirounga leonina: Boyd \& Arnbom 1991, Hindell et al. 1991, McConnell et al. 1992, see also Costa 1993). Inversely, temporal changes in predator behaviour are likely to provide an insight into the spatial distribution of marine resources. Furthermore, the use of temperature sensing may provide a new dimension in analysing marine mammal foraging ecology that may be useful for others purposes, such as fisheries management and oceanographic studies

Surprisingly, there are very few investigations of foraging behaviour in relation to oceanographic features in otariids. This may be due to the fact that fur seals generally feed in the vicinity of their colony during 1 to $8 \mathrm{~d}$ foraging trips (Gentry et al. 1986, Loughlin et al. 1987. Antonelis et al. 1990, Baba et al. 1991, Boyd et al. 1991, 1998, Harcourt et al. 1994). Furthermore, most studies of otariids have described the foraging behaviour of species in relation to the distribution of their potential prey, but marine resources have never been directly measured during these studies. Recent results suggest that studying fur seals may be a good way to investigate the relationships between environmental heterogeneity and foraging behaviour in a top predator. For example, Guadalupe Arctocephalus townsendi and Juan Fernandez A. philippii fur seals perform long foraging trips ( $11 \mathrm{~d}$ in summer) and travel about 450 and $600 \mathrm{~km}$ offshore, respectively (Figueroa 1994, Francis et al. 1998). The large range of foraging zones for these temperate species suggests that the seals encounter a wide variety of oceanographic conditions during their trips as they appear to leave the poorly productive, insular system for areas where their main prey (myctophids and cephalopods) are more abundant (Figueroa 1994, Francis et al. 1998).

In the Subantarctic fur seal Arctocephalus tropicalis, the pup-rearing period lasts 10 to 11 mo (Tollu 1974). During this time lactating females alternate at-sea foraging trips, during which they exploit marine resources, with attendance periods ashore to feed their pup. On Amsterdam Island, Subantarctic fur seals have a protracted attendance pattern, with lactating females foraging at sea for $11 \mathrm{~d}$ in summer and up to $23 \mathrm{~d}$ in winter, while they nurse their pups during $4 \mathrm{~d}$ visits ashore (Georges \& Guinet 2000). The increase in forag- ing trip duration (Georges \& Guinet 2000) and in diving effort (Georges et. al. 2000) throughout the long pup-rearing period suggests that oceanographic conditions are likely to change seasonally near Amsterdam Island. In this study, we investigated the foraging habitat of lactating Subantarctic fur seals during 3 consecutive breeding seasons to assess the relationships between the oceanographic environment (sea-surface temperatures [SST] and frontal structures) and the at-sea distribution of fur seals. Secondly, we investigated the way in which this predator exploits the marine environment by monitoring changes in diving activity in relation to SST throughout foraging trips.

\section{MATERIAL AND METHODS}

Study site and seals. This study was carried out on the colony 'La Mare aux Elephants', Amsterdam Island $\left(37^{\circ} 50^{\prime} \mathrm{S}, 77^{\circ} 30^{\prime} \mathrm{E}\right)$, Indian Ocean, during 3 consecutive breeding seasons (from 1995 to 1997). Amsterdam Island lies $3000 \mathrm{~km}$ east of South Africa, $3000 \mathrm{~km}$ west of Australia, and $400 \mathrm{~km}$ north of the Subtropical Front (STF). There is no peri-insular shelf, and water depth increases from 0 to $500 \mathrm{~m}$ within about $2 \mathrm{~km}$. Approximatively 50000 fur seals breed on Amsterdam Island (Guinet et al. 1994).

Oceanographic conditions were obtained from the Integrated Global Ocean Service System (IGOSS) database (http://ingrid.ldgo.columbia.edu), considering weekly mean SST blended from ship, buoy and biascorrected satellite data (Reynolds \& Smith 1994). Seasonal distributions of SST for the study area and southem oceanographic features were similar among years (Fig. 1). In summer (December to February) sea-surface isotherms were latitudinally distributed, indicating that

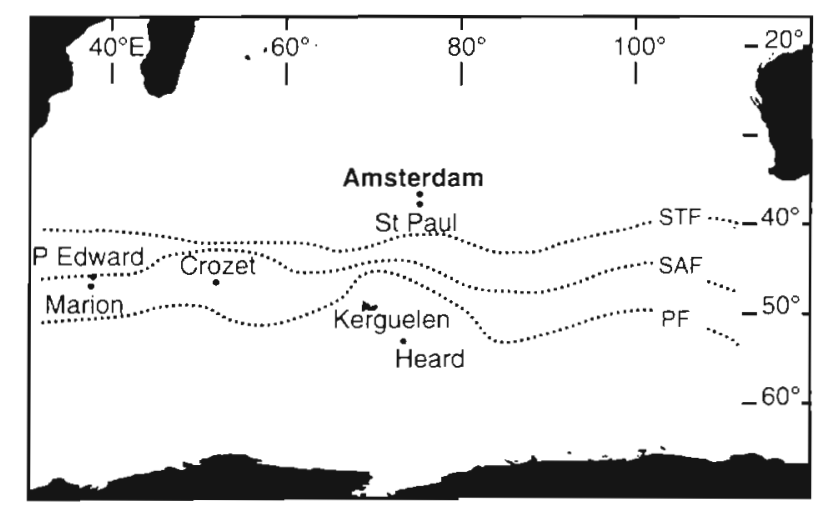

Fig. 1 Study area and oceanographic context according to frontal structures in summer (Lutjeharms \& Valentine 1984 Belkin \& Gordon 1996). STF: Subtropical Front (axial SST = 14. $2^{\circ} \mathrm{C}$ ), SAF: Subantarctic Front (axial SST $=8.0^{\circ} \mathrm{C}$ ), PF: Polar Front $\left(\right.$ axial SST $=4$ to $5^{\circ} \mathrm{C}$ ) 
SST decreased regularly with increasing latitude. The major frontal structure in the study area is the STF $\left(10.6\right.$ to $17.9^{\circ} \mathrm{C}$, axial SST $14.2^{\circ} \mathrm{C}$, Lutjeharms \& Valentine 1984, Belkin \& Gordon 1996), which is in the vicinity of Amsterdam Island in December (period of the first trip after parturition), about $400 \mathrm{~km}$ south in summer, and 250 to $550 \mathrm{~km}$ north in winter (Table 1). In winter (July), the SST gradient of the STF (the latitudinal change in SST on Amsterdam Island's longitude) was weak compared to the summer gradient. South of the STF, there was a high SST gradient delimited in the north and south by the Subantarctic Front (SAF) and the Polar Front (PF), respectively (Fig. 1). The distance between Amsterdam Island and the STF, and the SST gradient of the STF varied between seasons and years (Table 1).

Foraging behaviour was investigated in 34 lactating fur seals using 3 different techniques: time depth recorders (TDRs), satellite platform transmitter terminals (PTTs), and a direction recorder. TDRs (Wildlife Computers, Redmond, WA, USA), MK5 (28 seals) and MK6 (1 seal), were deployed over the 3 yr to investigate diving activity and record sea temperatures during foraging trips. The MK5 TDRs were programmed to sample dive depth $( \pm 1 \mathrm{~m})$ for depths $\geq 3$ m every $10 \mathrm{~s}$, while the MK6 speed TDR recorded depth and swimming speed $\left( \pm 0.05 \mathrm{~m} \mathrm{~s}^{-1}\right.$ ) every $10 \mathrm{~s}$ when wet. For 20 of the 29 TDRs, sea temperatures were effective $\left( \pm 0.1^{\circ} \mathrm{C}\right)$ every $10 \mathrm{~s}$. Calibration of temperature recorders in a thermostatic-controlled bath after the study indicated that all recorders were highly effective $\left( \pm 0.1^{\circ} \mathrm{C}\right)$ in the considered temperature range (from +5 to $+30^{\circ} \mathrm{C}, \mathrm{M}$. A. Lea \& Y. Tremblay pers. comm.). Daily SST was defined as the average value of sea temperature recorded when TDRs were between surface and $3 \mathrm{~m}$ depth between 23:00 and 01:00 h local time, in order to reduce bias related to the warming up of SST during the day. SST data recorded by TDRs were compared to independent measurements of mean weekly SST obtained from the IGOSS database (Reynolds \& Smith 1994). We used TDRs and IGOSS SST data as a locational cue, and the minimum foraging range was determined by the nearest position corresponding to the extreme (minima or maxima) SST values recorded by TDRs throughout the trip. In February-March 1995, 4 seals were fitted with satellite PTTs (Toyocom T-2038, Tokyo, Japan: weight $208 \mathrm{~g}$, i.e. $0.4 \%$ of seal body mass, $7 \mathrm{~cm}^{2}$ cross-sectional area) with a continuous transmission interval of $30 \mathrm{~s}$. Locations provided by the Argos (Toulouse, France) system were assigned to 1 of 4 accuracy classifications: Class 3 , accurate to $150 \mathrm{~m}$. Class 2 to $350 \mathrm{~m}$, Class 1 to $1 \mathrm{~km}$, and Class 0 has no accuracy assigned (Service Argos 1984). In February 1996,1 seal was fitted with a direction recorder (weight $29 \mathrm{~g}, 87 \mathrm{~mm} \times 24 \mathrm{~mm} \times 15 \mathrm{~mm}$, sampling rate 16 s; see
Table 1. Monthly sea-surface temperature (SST) near Amsterdam Island, latitude of the Subtropical Front (STF) at the Amsterdam Island's longitude, distance between Amsterdam Island and the STF (axial SST $=14.2^{\circ} \mathrm{C}$ ) with relative position (N: north, S: south of Amsterdam Island), and SST gradient of the STF during the study period

\begin{tabular}{|lcccc|}
\hline Season & $\begin{array}{c}\text { SST Ams } \\
\left({ }^{\circ} \mathrm{C}\right)\end{array}$ & $\begin{array}{c}\text { STF latitude } \\
\left({ }^{\circ} \mathrm{S}\right)\end{array}$ & $\begin{array}{c}\text { Distance } \\
(\mathrm{km})\end{array}$ & $\begin{array}{c}\text { SST gradient } \\
\left({ }^{\circ} \mathrm{C} 100 \mathrm{~km}^{-1}\right)\end{array}$ \\
\hline Feb 95 & 18.3 & 41.7 & $430(\mathrm{~S})$ & 0.853 \\
Jul 95 & 13.2 & 35.5 & $250(\mathrm{~N})$ & 0.487 \\
Dec 95 & 15.0 & 39.2 & $150(\mathrm{~S})$ & 0.632 \\
Feb 96 & 17.1 & 41.9 & $450(\mathrm{~S})$ & 0.853 \\
Jul 96 & 12.5 & 33.0 & $550(\mathrm{~N})$ & 0.466 \\
Dec 96 & 15.0 & 39.5 & $190(\mathrm{~S})$ & 0.664 \\
Jan 97 & 16.9 & 41.3 & $390(\mathrm{~S})$ & 0.891 \\
& & & & \\
\end{tabular}

Dall'Antonia et al. 1995) to monitor changes in direction during the trip. The route was calculated considering the average speed calculated per day and night according to MK6 data.

All devices were streamlined to reduce drag disturbance. The devices were fixed with nylon ties to pieces of velcro slightly larger than the base of the instrument, which were then glued with quick-set epoxy to the fur between the shoulders (PTTs and TDRs in 1995) or $10 \mathrm{~cm}$ from the tail (direction recorder and TDRs in 1996 and 1997). Nylon ties were cut to recover the devices after 1 foraging trip. TDR data were analysed using software provided by Wildlife Computers. The seal equipped with the MK6 speed recorder was considered to be resting for speeds $\leq 0.05 \mathrm{~m} \mathrm{~s}^{-1}$, and as such that time spent resting and swimming at the surface $(\leq 3 \mathrm{~m}$ ) could be calculated.

Organisation of the foraging trip. For the foraging trips where diving behaviour was monitored over the whole duration, the organisation of the trip was investigated in terms of changes in diving activity according to 3 different indices calculated for each day spent at sea: (1) dive frequency (number of dives $\mathrm{h}^{-1}$ ), (2) hourly vertical distance travelled (sum of the maximum depth of the dives occuring per hour, multiplied by 2 , Horning \& Trillmich [1997], in $\mathrm{m} \mathrm{h}^{-1}$ ), and (3) time spent diving per hour (sum of the duration of the dives occuring per hour, in $\min \mathrm{h}^{-1}$ ). In Subantarctic fur seals, 99\% of the diving activity occurs at night (Georges et al. 2000), so that diving activity indices were calculated per hour of night. For each individual and each diving index, an iterative statistical method (Boyd et al. 1994) was used twice to determine distinct phases throughout the foraging trip according to changes in diving activity. This iterative method relies on searching the day for a change in diving activity which differed significantly from the previous set of diving activity since the last significant change: the day was searched sequentially from the start and once a group of days had satisfied 
this minimum requirement, a search was made through the subsequent days to find the end of the phase. This was done by comparing the mean diving activity between days within the phase and next days of the trip. If the diving activity differed significantly from the defined phase for at least 2 of the indices, then the phase was deemed to have ended. If non significantly different for at least 2 of the 3 indices, it was included within the phase, the mean index for the phase was recalculated and the search for the end of the phase was continued. Statistical threshold was fixed at 0.1 because of the small number of days during a given foraging trip. The same procedure was conducted in reverse, i.e. the iterative process was begun at the last day of the foraging trip. For all of the trips where different phases were determined using the first iterative method, the same phases were determined using the second iterative method, indicating that both methods allowed the same organisation of the foraging trips when considering the 3 indices used in this study to be determined. Statistical analyses were run using Systat 7.0 statistical software (Systat, SPSS Inc.) according to Sokal \& Rohlf (1981). Means are given $\pm \mathrm{SE}$.

\section{RESULTS}

\section{Foraging habitat and sea-surface temperatures}

First trip after parturition

SST were recorded for 6 of the 7 seals fitted with a TDR during their first foraging trip after parturition (4 in December 1996, and 2 in December 1997. Table 2). Seals spent $6.7 \pm 0.6 \mathrm{~d}$ at sea $(\mathrm{n}=7)$ and foraged in waters where SST were between 14.7 and $16.6^{\circ} \mathrm{C}$, i.e. less than $1{ }^{\circ} \mathrm{C}$ different to those at Amsterdam Island. Thus, $87 \%$ of the time recorded at sea was spent within the 15.5 to $16.5^{\circ} \mathrm{C}$ range, and $52 \%$ within the 15.5 to $16.0^{\circ} \mathrm{C}$ range (Fig. 2). According to IGOSS SST distributions, sea temperature records indicate that foraging range was between 60 and $130 \mathrm{~km}$ from Amsterdam Island (Table 2). The remaining seal (TDR 9606) for which SST was not recorded performed the shortest trip, suggesting that this seal also foraged in the vicinity of Amsterdam Island.

\section{Summer}

Satellite tracking allowed the determination of the movement in 4 lactating fur seals monitored from 27 January to 19 February 1995 . Unfortunately, seals were monitored for no more than $12 \mathrm{~d}$ at sea, because of battery failures, probably due to the high emitting fre- quency of the devices. A total of 29 fixes were recorded at sea: $72.4 \%$ class $0,17.2 \%$ class $1,3.4 \%$ class 2 , and $7.0 \%$ class 3 . The general direction of travel obtained for each seal is shown in Fig. 3 and data relative to each route are given in Table 3 . All seals were oriented south-east, using a parallel straight route from Amsterdam Island during the first days at sea. With regards to

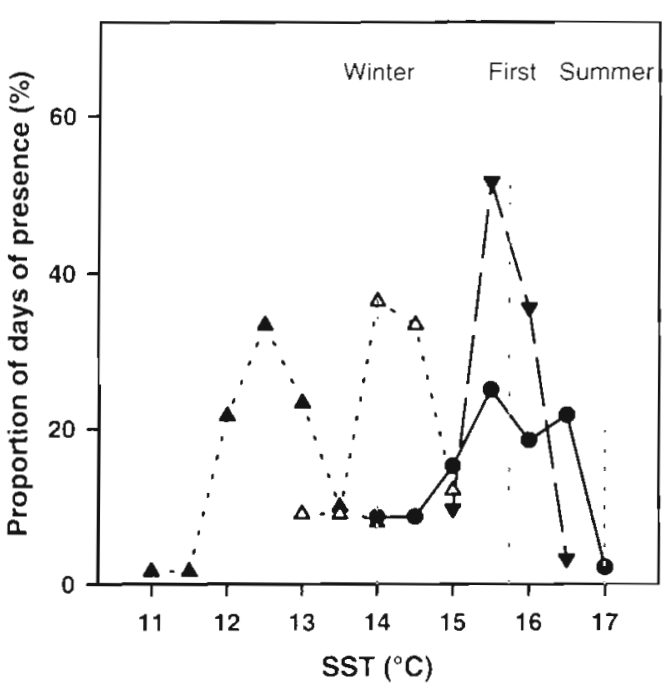

Fig. 2. Proportion of days recorded at sea spent in SST classes during the first trip after parturition ( $\mathbf{\nabla})$, in summer $(\bullet)$, and in winter (trips southwards: $\Delta$, northwards: $\Delta$ ). The dashed lines represent the seasonal SST around Amsterdam Island

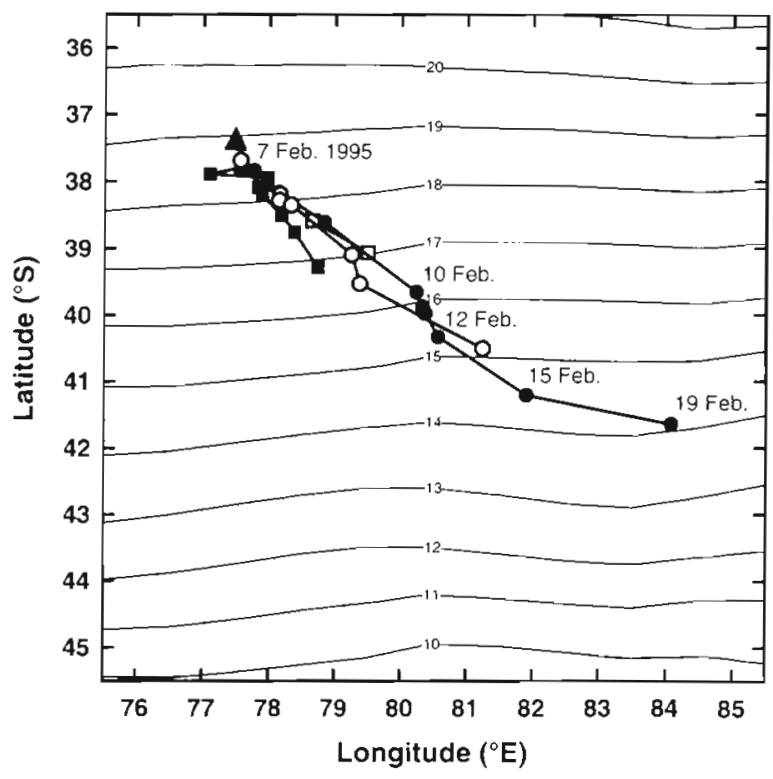

Fig. 3. Satellite tracks of lactating Subantarctic fur seals in February 1995 with corresponding SST map obtained from the IGOSS database. (A) Amsterdam Island. Details are given for seal 2360 monitored over $12 \mathrm{~d}$ 


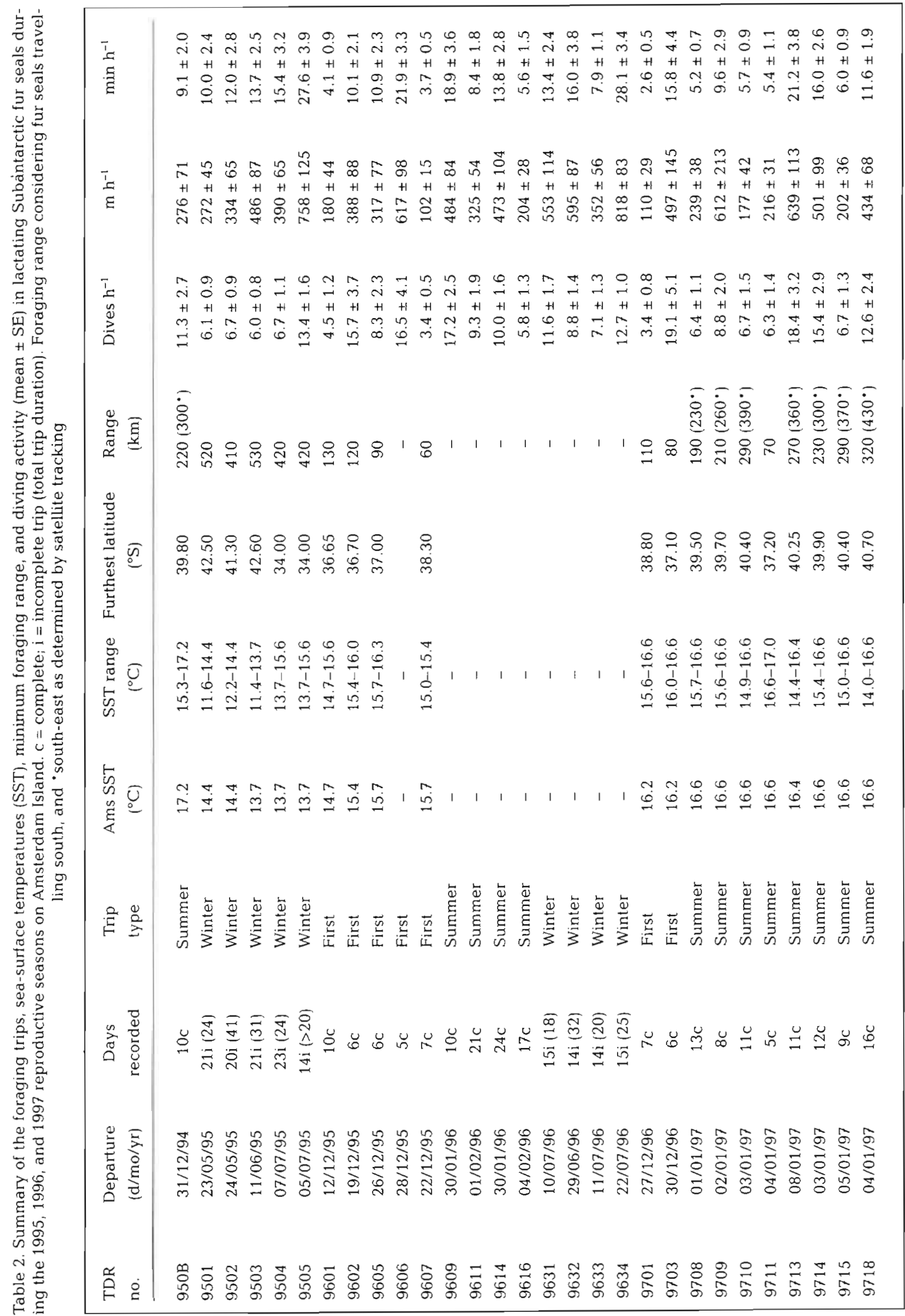


Table 3. Satellite tracking data of lactating Subantarctic fur seals monitored during the austral summer 1995. PTT = platform transmitter terminal.

\begin{tabular}{|c|c|c|c|c|c|c|c|c|c|}
\hline $\begin{array}{l}\text { PTT } \\
\text { no }\end{array}$ & $\begin{array}{l}\text { Departure } \\
\text { date/time }\end{array}$ & $\begin{array}{l}\text { Arrival } \\
\text { date }\end{array}$ & $\begin{array}{l}\text { No. of } \\
\text { locations }\end{array}$ & Date/time & $\begin{array}{c}\text { - Last location } \\
\text { Position }\end{array}$ & $\operatorname{SST}\left({ }^{\circ} \mathrm{C}\right)$ & $\begin{array}{l}\text { Range } \\
(\mathrm{km})\end{array}$ & $\begin{array}{c}\text { Distance } \\
\text { covered }(\mathrm{km})\end{array}$ & $\begin{array}{c}\text { Average speed } \\
\qquad\left(\mathrm{km} \mathrm{d}^{-1}\right)\end{array}$ \\
\hline 28520 & 6 Feb/15:11 h & 22 Feb & 9 & $10 \mathrm{Feb} / 08: 21 \mathrm{~h}$ & $39.28^{\circ} \mathrm{S}, 78.74^{\circ} \mathrm{E}$ & 17.2 & 196 & 302 & 81.3 \\
\hline 23159 & $7 \mathrm{Feb} / 02: 27 \mathrm{~h}$ & 11 Mar & 3 & $9 \mathrm{Feb} / 23: 44 \mathrm{~h}$ & $39.06^{\circ} \mathrm{S}, 79.50^{\circ} \mathrm{E}$ & 17.2 & 218 & 240 & 108.4 \\
\hline 23160 & 7 Feb/02:29h & $13 \mathrm{Mar}$ & 10 & $19 \mathrm{Feb} / 0132 \mathrm{~h}$ & $41.64^{\circ} \mathrm{S}, 84.08^{\circ} \mathrm{E}$ & 14.2 & 706 & 730 & 61.0 \\
\hline 23161 & $27 \mathrm{Jan} / 14: 23 \mathrm{~h}$ & $15 \mathrm{Feb}$ & 7 & $31 \mathrm{Jan} / 13: 31 \mathrm{~h}$ & $40.51^{\circ} \mathrm{S}, 81.25^{\circ} \mathrm{E}$ & 15.5 & 441 & 462 & 116.6 \\
\hline
\end{tabular}

the distribution of the SST, seals were oriented towards colder waters rather than those surrounding Amsterdam Island (Fig. 3). Seal 23160 (monitored during a $12 \mathrm{~d}$ period) travelled on a straight route for $3.6 \mathrm{~d}$ until reaching the $16.0^{\circ} \mathrm{C}$ isotherm. The seal then spent $8.3 \mathrm{~d}$ in waters where SST were between 14.0 and $16.0^{\circ} \mathrm{C}$. The last 3 locations suggest that the route did not cross the $14.0^{\circ} \mathrm{C}$ surface isotherm

A direction recorder was deployed on one seal that spent $26 \mathrm{~d}$ at sea during the summer of 1996. Records stopped after $10 \mathrm{~d}$ at sea because of insufficient memory. Analysis of the route suggests that 2 main phases occurred during the recording (Fig. 4). The seal left the colony in the evening on 28 January and travelled in a straight south-easterly direction for 6 nights and $5 \mathrm{~d}$, without an apparent change in route. The seal was $530 \mathrm{~km}$ far from Amsterdam Island (SST $=12.8^{\circ} \mathrm{C}$ ) on the sixth day when it returned, travelling north-west for the whole day. On the seventh night at sea, the seal

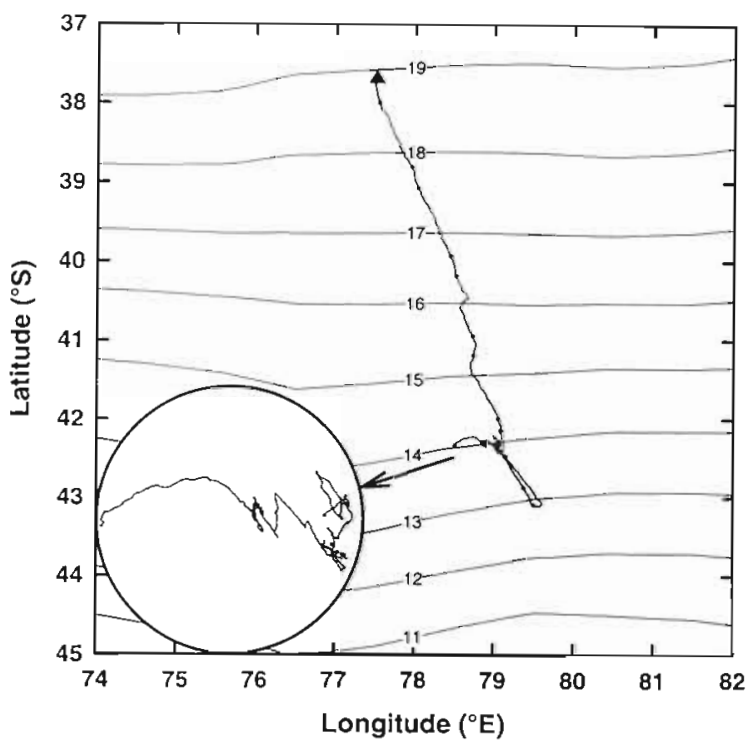

Fig. 4. Foraging route of the lactating Subantarctic fur seal monitored with a direction recorder in February 1996 with corresponding SST map obtained from the IGOSS database. The last days monitored are shown in detail in the circle. (A) Amsterdam Island changed its behaviour significantly and showed marked changes in direction within a $30 \mathrm{~km}$ radius area where SST was $14.0^{\circ} \mathrm{C}$. Numerous changes in direction and loops occurred for 3 days and nights. The seal then travelled westwards during the last day recorded, and remained on the same latitude as during the previous days.

SST were recorded for 9 seals using TDRs (1 in January 1995, 8 in January 1997, Table 2). There was a decrease in SST during the first days after departure for all but 1 seal (TDR 9711) monitored in 1997, indicating that seals were travelling southwards. For these seals, 58\% of the time recorded at sea was spent within the 14.0 to $16.0^{\circ} \mathrm{C}$ range (Fig. 2). The minimum SST reached during the trip ranged between 14.0 and $15.7^{\circ} \mathrm{C}$. The lowest temperatures $\left(\leq 15.0^{\circ} \mathrm{C}\right)$ were reached by 4 seals, and all other seals reached waters as cold as between 15.3 and $15.7^{\circ} \mathrm{C}$. According to SST distributions, the minimum foraging range was between 190 and $320 \mathrm{~km}$ if all seals were considered to be travelling southwards. The foraging range was between 230 and $430 \mathrm{~km}$ if seals were considered to be travelling in the same south-easterly direction as indicated by satellite tracking. The remaining seal (TDR 9711) performed a short $5 \mathrm{~d}$ trip and reached warmer waters $\left(17.0^{\circ} \mathrm{C}\right)$ that were $70 \mathrm{~km}$ north from Amsterdam Island. In January 1995, 1 seal (TDR 950B) monitored reached waters where SST was $15.3^{\circ} \mathrm{C}, 270 \mathrm{~km}$ south from Amsterdam Island, and $300 \mathrm{~km}$ to the south-east.

\section{Winter}

In winter (June-July 1995), 3 of the 5 foraging trips were associated with a decrease in the SST during the first days, indicating that these 3 seals were moving southwards. The minimum SST reached by these seals were between 11.4 and $12.2^{\circ} \mathrm{C}$ (between 410 and $530 \mathrm{~km}$ south of Amsterdam Island), $55 \%$ of the time being spent in waters between 12.0 and $13.0^{\circ} \mathrm{C}$. The other 2 foraging trips were associated with an increase in SST up to $15.3^{\circ} \mathrm{C}(420 \mathrm{~km}$ north of Amsterdam Island), with $70 \%$ of the recorded days being spent in waters between 14.0 and $15.0^{\circ} \mathrm{C}$ (Fig. 2). 


\section{Diving activity throughout the trip}

First foraging trip

During the first trip following parturition, diving activity averaged $10.1 \pm 2.6$ dives $h^{-1}, 316 \pm 74 \mathrm{~m} \mathrm{~h}^{-1}$ ( $2 \times$ sum of maximum depths per hour of night), and $9.9 \pm 2.7 \mathrm{~min} \mathrm{~h}^{-1}$ (sum of dive durations per hour of night). The iterative method did not show significant changes in these parameters throughout the trip for any seal (Fig. 5). Interannual comparisons were not performed because of small sample sizes. Mean diving activity calculated throughout the trip varied among seals, with 3 seals showing a lower diving activity than the 4 others (Table 2).

\section{Summer}

Twelve lactating fur seals were monitored with TDRs in February $1996(n=4)$ and January $1997(n=8)$. Foraging trips tended to be shorter in January 1997 (10.6 \pm 1.1 d) than in February 1996 (18.0 \pm 3.0 d, Mann-Whitney test $U=27, \mathrm{p}=0.061$ ). In February 1996, diving activity averaged $10.6 \pm 2.4$ dives $\mathrm{h}^{-1}, 372 \pm 66 \mathrm{~m} \mathrm{~h}^{-1}$ and $11.7 \pm 3.0 \mathrm{~min} \mathrm{~h}^{-1}$ and did not differ to that in January $1997\left(10.1 \pm 1.7\right.$ dives $h^{-1}, 376 \pm 68 \mathrm{~m}$ $\mathrm{h}^{-1}$, and $10.1 \pm 2.1 \mathrm{~min}^{-1} ; U=17, \mathrm{p}=$ 0.865; $U=16, \mathrm{p}=0.999 ; U=19, \mathrm{p}=0.61$, respectively). Diving activity varied among individuals (Table 2) and for all seals but one (TDR 9711), the diving activity varied throughout the foraging trip according to 3 distinct phases during the 2 yr according to a similar pattern (Tables $4 \& 5$ ). During the first phase that lasted $2.7 \pm 0.3 \mathrm{~d}(16 \%$ of the trip duration) in 1996 and $3.2 \pm 0.5 \mathrm{~d}$ $(28 \%)$ in 1997 , the diving activity was significantly lower (iterative method, $\mathrm{p}<0.1$ ) than during the rest of the trip (Table 5, Fig. 5). In 1997 when SST was recorded, the first phase was associated with a decrease in SST that reached on average $15.6 \pm 0.2^{\circ} \mathrm{C}(\mathrm{n}=7)$ in the last day of the phase. Dive frequency calculated during the first phase in 1996 tended to be lower than in 1997 (Table 5). The second phase lasted on average $5.4 \pm 0.7 \mathrm{~d}(47 \%)$ in January 1997 and $9.2 \pm 2.3$ d $(51 \%)$ in February 1996 and was characterised by a high increase in diving activity, about 3 and 6 to 7 times higher than during the first phase in 1997 and 1996, respectively (Table 5, Fig. 5). SST recorded in the first day of the second phase was significantly colder than in the last day of the first phase (paired $t$-test: $t=3.378$, $\mathrm{p}=0.015, \mathrm{n}=7$ ). During the last phase (1996: $6.0 \pm$ $1.5 \mathrm{~d}, 33 \% ; 1997: 2.7 \pm 0.7 \mathrm{~d}, 25 \%$ ) diving activity decreased to half that of the second phase. SST recorded in the first day of the last phase averaged $16.0 \pm 0.3^{\circ} \mathrm{C}$ and was significantly warmer than that recorded for the last day of the second phase (paired $t$-test: $t=3.873, \mathrm{p}=0.008$ ). There were no significant differences in dive depth and dive duration among phases for most individual seals (ANOVA per individual, $\mathrm{p}>0.1$ in $80 \%$ of cases). Individual analyses for 3 seals (TDRs 9709, 9710, 9715) indicate that the first phase was longer than the last phase, and was associated with a higher diving activity than during the last phase (Table 4).

Average nightly SST for 7 seals travelling southwards in 1997 was classified according to $0.5^{\circ} \mathrm{C}$ intervals (Fig. 6). It differed significantly from the distribution of the total time spent diving per $0.5^{\circ} \mathrm{C}$ intervals $\left(\chi_{6}{ }^{2}=14.184, p=0.028\right)$. Contrast tests (Neu et al. 1974) indicate that the time spent diving in waters where SST was between 14.0 and $16.0^{\circ} \mathrm{C}$ was significantly higher $(p<0.05$ ) than expected according to the number of nights spent in these waters, whereas it was significantly lower in waters between 16.0 and $17.0^{\circ} \mathrm{C}$ (Fig. 6).

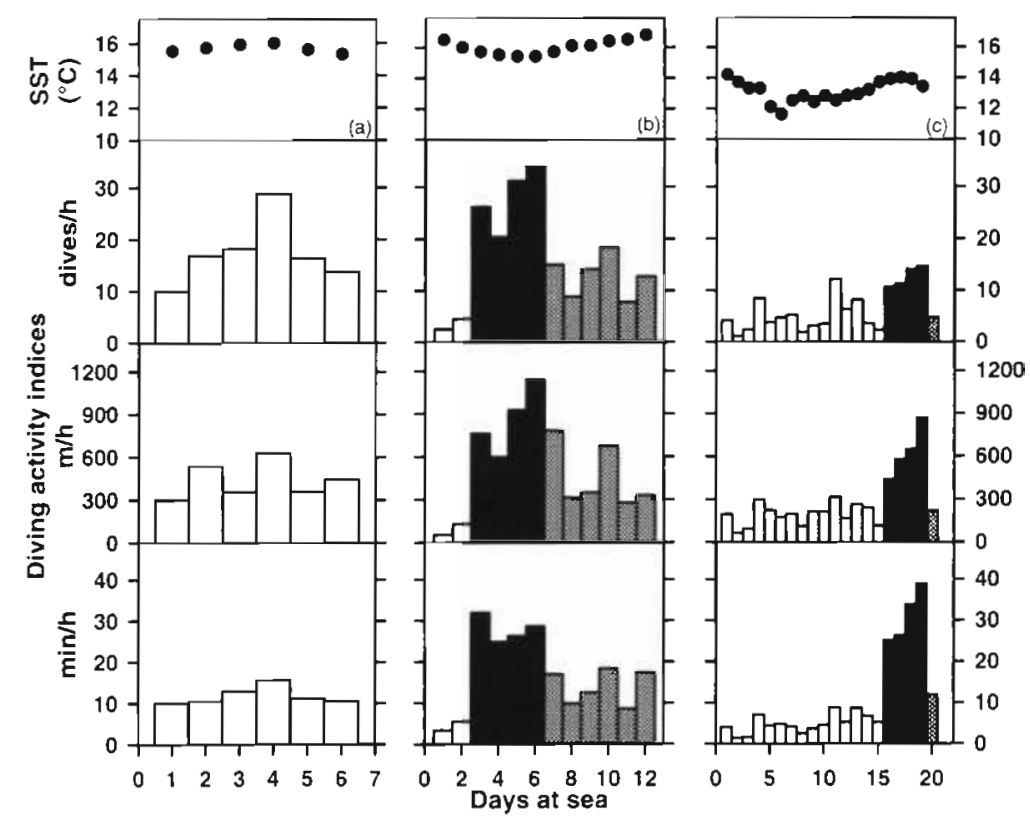

Fig. 5. Typical example of changes in SST and diving activity indices (dive frequency in dives $\mathrm{h}^{-1}$, sum of maximum dive depths $\times 2$, in $\mathrm{m} \mathrm{h}^{-1}$, and sum of dive durations, in min $\mathrm{h}^{-1}$ ) throughout the foraging trips (a) following parturition, (b) in summer, and (c) in winter. Distinct phases determined by significant changes in diving activity (see 'Material and methods') are represented by changes in color bars. One individual is shown by season 


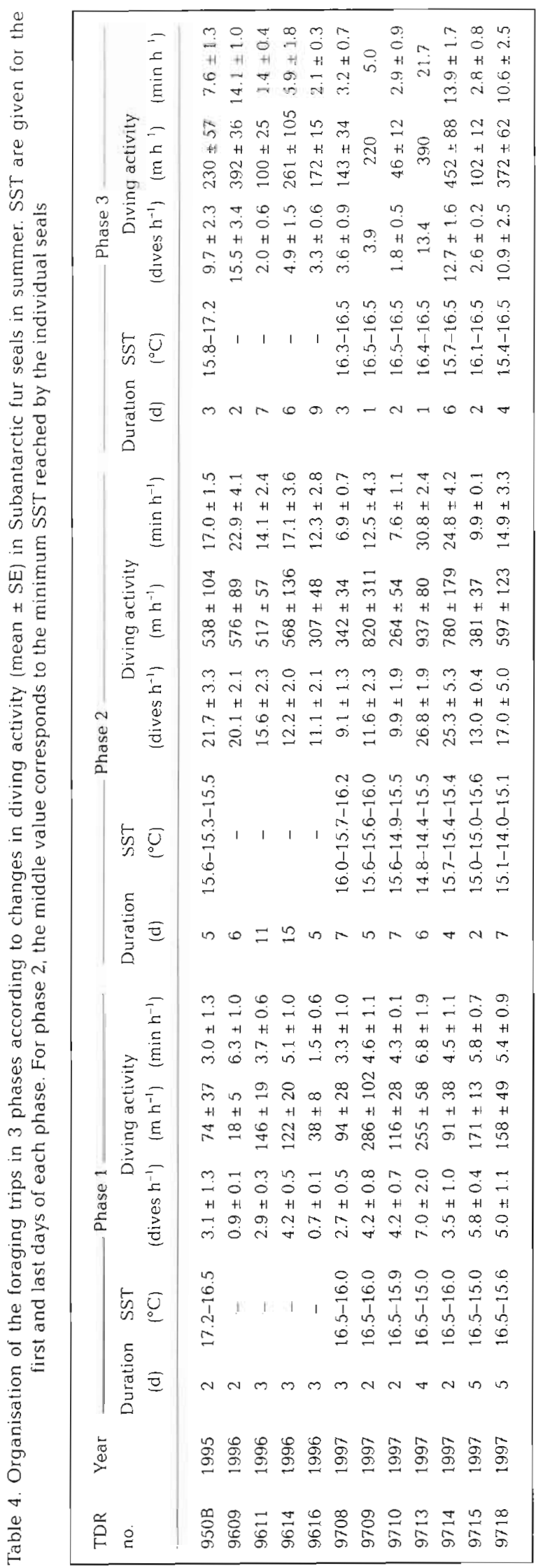

Days of presence (expected distribution) Time spent diving (observed distribution)

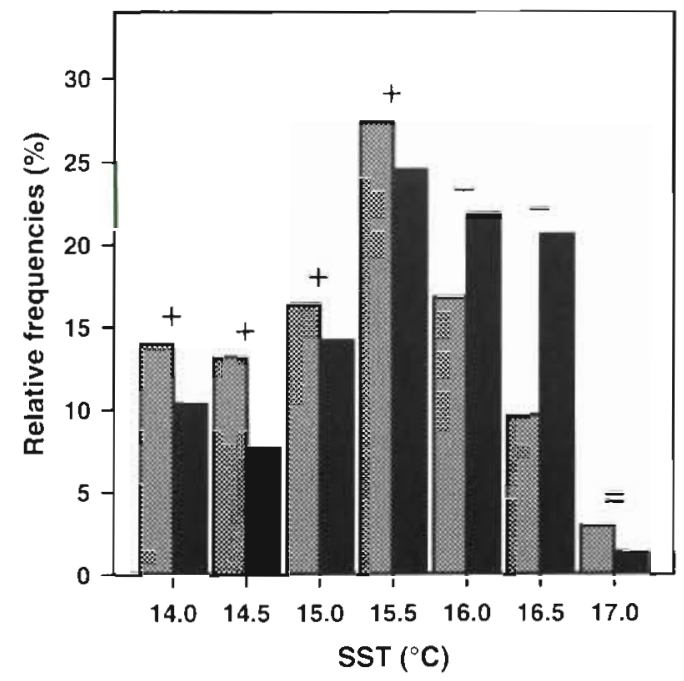

Fig. 6. Results of contrast test of comparisons between the expected distribution (number of nights spent in $0.5^{\circ} \mathrm{C}$ range, black bars) and the observed distribution (total time spent diving in $0.5^{\circ} \mathrm{C}$ range, white bars). +: time spent diving was significantly $(p<0.05)$ higher than expected, -: time spent diving was less than expected, according to the theoretical distribution

For the only seal that reached warmer waters in January 1997 (TDR 9711), diving activity did not vary significantly throughout the trip and was similar to that observed for 7 seals during their first foraging trip. In January 1995, seal 950B, which foraged in colder waters (Table 5) showed a similar foraging pattern to those seals monitored in January 1997.

\section{Winter}

Nine fur seals were monitored using TDRs during 2 consecutive austral winters, in June-July $1995(\mathrm{n}=5$ ) and July $1996(n=4)$. Despite the fact that all TDRs were retrieved with their memory capacity filled because of the long time spent at sea, diving activity calculated during the days monitored averaged $9.2 \pm$ 1.2 dives $\mathrm{h}^{-1}, 530 \pm 74 \mathrm{~m} \mathrm{~h}^{-1}$ and $16.8 \pm 2.8 \mathrm{~min} \mathrm{~h}^{-1}(\mathrm{n}=$ $9)$, and did not vary between years $(U=4, p=0.14 ; U=$ $5, p=0.221 ; U=9, p=0.806$; Table 2). For the 2 seals that came back less than $2 \mathrm{~d}$ after TDR memories were filled, diving activity changed according to 2 phases that differed between individuals. For seal 9501 (Fig. 5), the $16 \mathrm{~d}$ first phase was associated with a low diving activity that increased significantly during the 4 remaining days recorded. Seal 9504 showed the inverse pattern, with high diving activity during the first days, and low activity during the remaining days at sea. 
Table 5. Organisation of the foraging trips in summer, duration of the phases and diving activity (mean \pm SE) during each phase. Statistics for annual comparisons between 1996 and 1997 are given at the bottom of the table

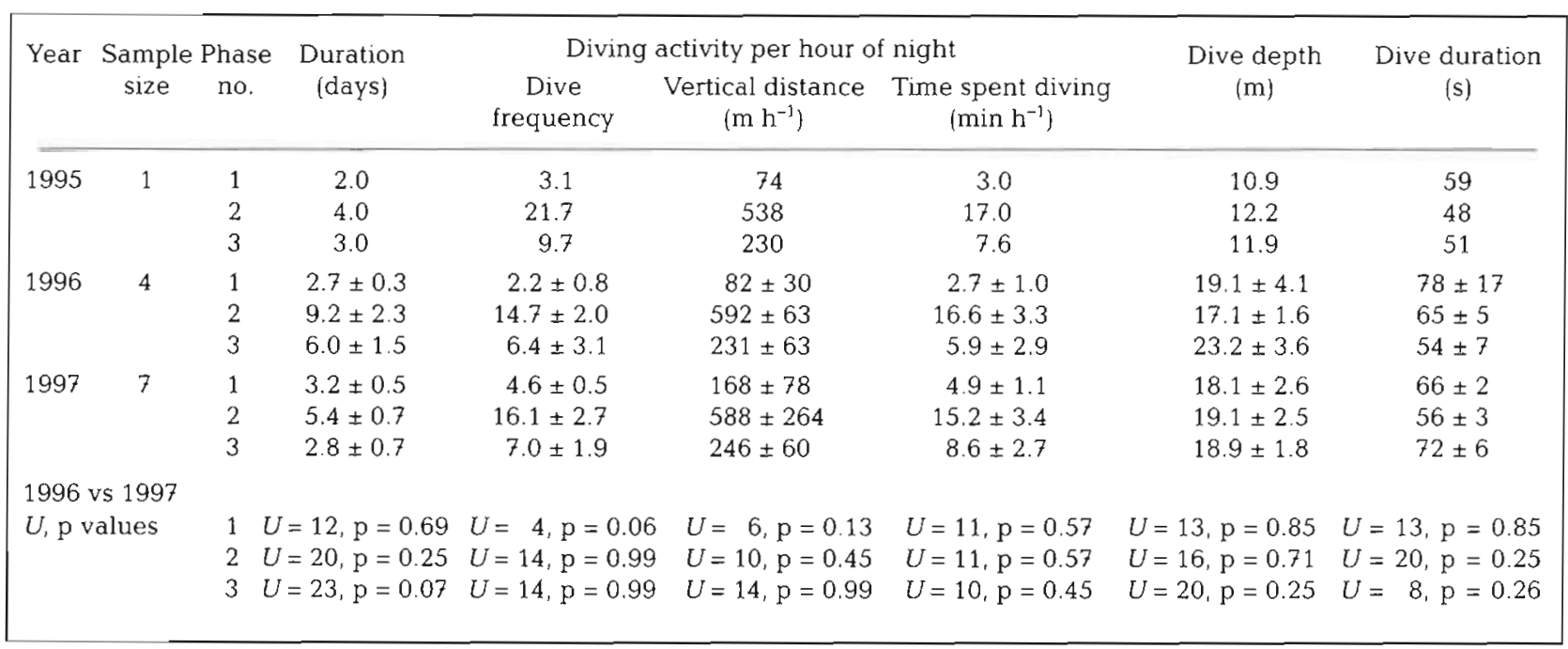

\section{Activity budget}

In January 1997, seal 9718 was fitted with an MK6 speed TDR throughout the trip, so that distance travelled horizontally at the sea-surface was calculated for each day and night spent at sea. The total distance travelled during the whole foraging trip was $590 \mathrm{~km}$ and is summarized in Fig. 7. The iterative method allowed 3 different phases according to seal's diving activity to be determined (Table 4). The activity budget over the trip was investigated in terms of time spent resting and swimming at the sea surface, and diving (Table 6). The seal spent no time resting during the night throughout the trip. During the first phase, the seal spent most of its time swimming during the day and night, and swam more rapidly during the night than during the day (Table 6). However, the distance travelled horizontally was similar during the day $\left(21.8 \pm 2.4 \mathrm{~km} \mathrm{~d}^{-1}\right)$ and during the night $\left(28.7 \pm 3.1 \mathrm{~km} \mathrm{~h}^{-1}\right.$ night, $U=8$, $\mathrm{p}=0.11$ ), because of differences in the durations between day $(15.7 \mathrm{~h})$ and night (8.3). During the second phase, the seal spent less time swimming horizontally and more time resting at the surface during the day than during the night compared to the other phases, and was consistent with the high diving activity during this phase. The seal swam more rapidly at the sea surface during the night than during the day, and travelled $6.2 \pm 0.9 \mathrm{~km} \mathrm{~d}^{-1}$, and $18.7 \pm 5.0 \mathrm{~km} \mathrm{night}^{-1}(U=8, \mathrm{p}=0.035)$, consistent with the large amount of time spent resting during the day. During the last phase, the seal spent similar time swimming both during the day and the night (Table 6), and travelled more during the day (20.0 \pm $\left.4.7 \mathrm{~km} \mathrm{~d}^{-1}\right)$ than during the night $(9.3 \pm 0.6 \mathrm{~km}$ night ${ }^{-1}, U=12, \mathrm{p}=0.034$ ) while swimming at a similar speed (Table 6).

The time spent resting was negatively correlated to the distance travelled during the same day (Spearman correlation $\mathrm{r}_{\mathrm{s}}=-0.896, \mathrm{n}=16, \mathrm{p}<0.001$ ).

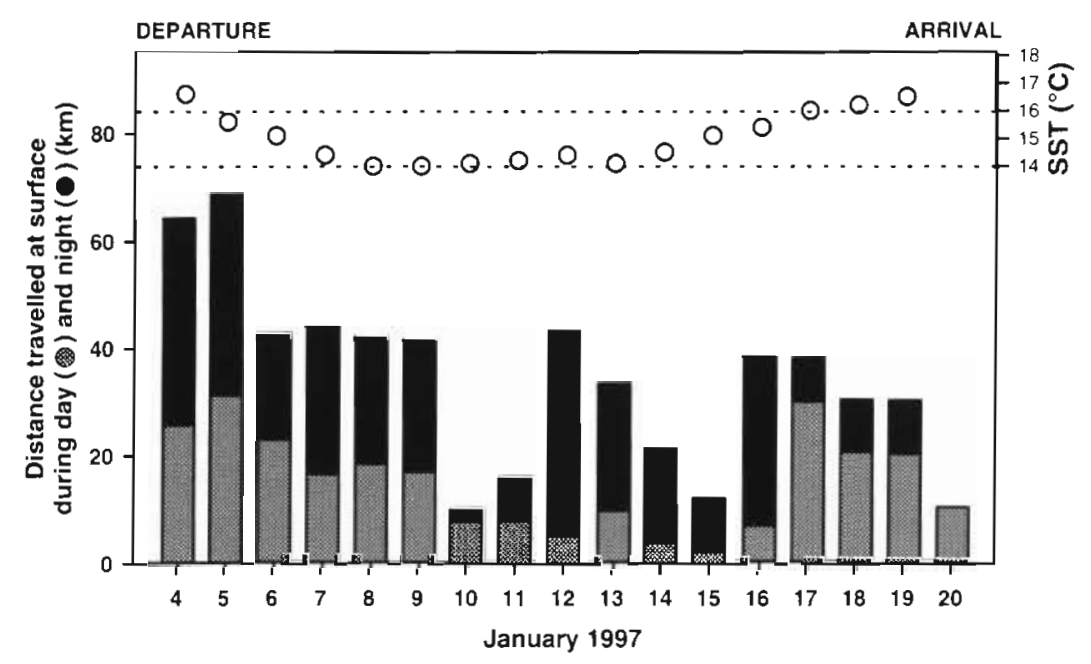

Fig. 7. SST encountered and swimming activity (distance travelled during the day and night) of seal 9718 monitored with an MK6 speed time depth recorder in January 1997 (see 'Results') 


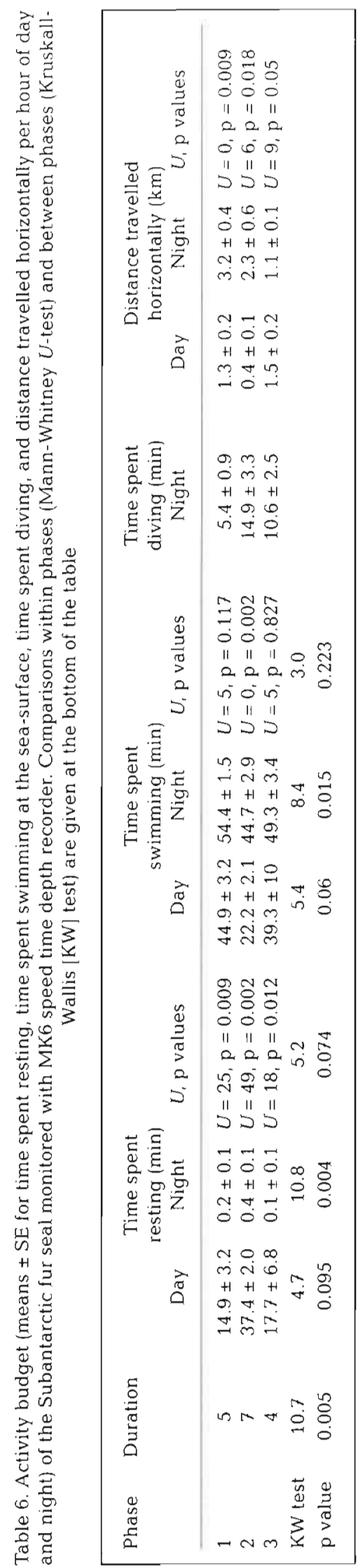

\section{DISCUSSION}

In this study we used time depth recorders, satellite transmitters, and a direction recorder to investigate the foraging habitat of the Subantarctic fur seal Arctocephalus tropicalis breeding on Amsterdam Island in relation to SST during 3 consecutive breeding seasons. We deployed TDRs equipped with a water temperature sensor in order to utilise water temperature as a locational cue according to satellite remote sensing of SST distribution (NOAA. IGOSS), as Weimerskirch et al. (1995) have shown that SST data obtained by IGOSS is highly representative of in situ SST. Furthermore, the foraging range calculated using SST data $(320 \mathrm{~km})$ for 1 seal was consistent with the total distance travelled calculated using the speed TDR (590 km round trip). We also investigated spatial and temporal behaviour throughout the foraging trip to determine how lactating fur seals exploit marine environment.

\section{Foraging habitat and oceanographic features}

This study is the first attempt to describe foraging habitat in relation to SST in a fur seal with a long puprearing period and a protracted attendance pattern (Georges \& Guinet 2000). Lactating Subantarctic fur seals breeding on Amsterdam Island forage in oceanic areas associated with 14.0 to $16.0^{\circ} \mathrm{C}$ surface isotherms, where they spend most of their time when at sea. They do not appear to forage in waters colder than $14^{\circ} \mathrm{C}$ (except for 3 seals in winter), suggesting that their foraging habitat is associated with the northern part of the STF (axial SST $=14.2^{\circ} \mathrm{C}$, Lutjeharms \& Valentine 1984). In the vicinity of Amsterdam Island, the STF forms one of the strongest horizontal temperature gradients of the Southern Indian Ocean (Deacon 1982, Lutjeharms \& Valentine 1984, Lutjeharms 1985) and is consequently a strong biogeographical boundary between subtropical and subantarctic communities (Pakhomov et al. 1994). Furthermore, the STF contributes substantially to the total productivity of the Southern Ocean (Lutjeharms et al. 1985, El Sayed 1988, Pakhomov et al. 1994), with $26 \%$ of the total biomass between 0 and $300 \mathrm{~m}$ being composed of myctophid fish (Pakhomov et al. 1994) which are the main prey consumed by Subantarctic fur seals (Klages \& Bester 1998, Y. Cherel, C. Guinet, J.-Y. Georges \& $\mathrm{S}$. Mangin unpubl. data). This is consistent with previous studies indicating that abundance and activity of seabirds (Abrams 1985, Bost et al. 1997, Guinet et al. 1997. Mehlum et al. 1998) and marine mammals (Machida 1974, Boyd \& Arnbom 1991, McConnell et al. 1992, Tynan 1998) are associated with frontal struc- 
tures. This also indicates that for most top predators, such as fur seals, food requirements can only be sustained by highly productive and seasonaly predictable oceanographic features, as proposed for whales (Tynan 1998), penguins and seals (Pakhomov \& Froneman 1999).

\section{Seasonal foraging strategies}

The present study indicates that at Amsterdam Island, Subantarctic fur seals show different foraging strategies in relation to the seasonal positions of the STF.

During the first trip after parturition, in December, lactating fur seals foraged between 60 and $130 \mathrm{~km}$ off Amsterdam Island, which is situated next to the STF, suggesting that at this time, coastal resources were not sufficient or appropriate for lactating females. Fur seals did not appear to change their diving activity throughout the first trip, suggesting that they used prey which were not patchily distributed in the vicinity of Amsterdam Island. In Subantarctic fur seals, parturition is associated with a $10 \mathrm{~d}$ perinatal period (during which mothers fast ashore to nurse their newborn pup, Georges \& Guinet in press) that has been reported as a highly energetically demanding time for the mothers (Costa \& Trillmich 1988). Mothers start to restore their body reserves during the first foraging trip, which is relatively short compared to following trips (Georges \& Guinet in press), probably in response to the low fasting ability of their newborn (Georges \& Guinet 2000). The proximity of the STF during this period appears to allow lactating females to restore their body reserves within a relatively short time which does not jeopardize the survival of the pup.

During the later foraging trips in summer (JanuaryFebruary), sea temperature sensors on TDRs, satellite transmitters, and a direction recorder indicated that 13 of the 14 seals performed long southward foraging trips to the northern part of the STF, 230 to $430 \mathrm{~km}$ (up to $730 \mathrm{~km}$ ) south from Amsterdam Island. The remaining seal performed a $5 \mathrm{~d}$ trip in early January 1997. suggesting that it was foraging in the vicinity of Amsterdam Island. In the present study, we used an iterative statistical method previously used by Boyd et al. (1994) to investigate changes in diving activity in terms of dive frequency, vertical travelled distance (sum of maximum dive depths), and time spent diving (sum of dive durations) per hour each night throughout the trip. During both summers monitored, foraging trips appeared to be organized in 3 distinct phases according to diving activity.

First phase. This phase was characterized by a low diving activity compared to the remaining days spent at sea, and was associated with a decrease in SST, indicating that seals were travelling continuously southwards, as was also indicated by the speed recorder, and the direction recorder. All seals fitted with satellite transmitters and the direction recorder consistently used a similar south-east route during 2 successive years. Interestingly, the seal fitted with a direction recorder swam a straight route without appearent changes in direction, while the seal fitted with a speed recorder swam continously during the first days at sea, suggesting that (1) they did not stop at night to dive, and (2) they were moving directly toward an apparently known foraging ground. Interestingly, northern fur seals swim directly to feeding areas of past feeding success (Loughlin et al. 1987) while Antarctic fur seals tend to travel away from the colony along a roughly constant bearing (Boyd 1999). Furthermore, northern (Antonelis et al. 1990) and Antarctic fur seals (Boyd et al. 1998, Bonadonna et al. 2000) show a similar strategy of foraging within a restricted area. Moreover, lactating fur seals appear to use the same area over consecutive years as observed in satellite-tracked Antarctic fur seals at South Georgia (Boyd et al. 1998) and Subantarctic fur seals at Amsterdam Island (unpubl. data). Individuals exploiting a known and successful foraging area are expected to perform shorter and more regular foraging trips than individuals spending energy and time in searching for unknown prey patches. Such a regular provisioning pattern has obvious consequences on the reproductive success of Subantarcic fur seals, as mothers performing short and regular foraging trips enable a higher growth rate and weaning mass for their pups, compared to other mothers (Georges \& Guinet 2000).

Second phase. This phase corresponded to an enhancement in diving activity that increased by 3 to 6-7 times (in 1997 and 1996, respectiveiy) when seals reached the coldest waters encountered during their foraging trip $\left(14.0\right.$ to $\left.16.0^{\circ} \mathrm{C}\right)$. In fur seals, diving is thought to reflect feeding activity because they remain at the surface for much of their time at sea (Georges et al. 2000) and dives are therefore excursions from the surface to forage. Hence, the high diving activity and the long duration of the second phase (about $50 \%$ of the trip duration for both years) suggest that it corresponds to the feeding phase of the trip. Data obtained with the direction and swimming speed recorders indicate that during the second phase, seals swam mostly during the night in a directionally irregular pattern while staying within a very restricted area and resting at the surface approximatively $10 \mathrm{~h} \mathrm{~d}^{-1}$ (Figs. 6 \& 7). All these results suggest that during southwards foraging trips in summer, Subantarctic fur seals concentrate their diving (feeding) activity on the STF (Lutjeharms \& Valentine 1984), where myctophid fish, their main 
prey (Klages \& Bester 1998, Y. Cherel et al. unpubl. data) are known to be abundant (Pakhomov et al. 1994). Recently, Georges et al. (2000) showed that lactating Subantarctic fur seals changed their diving behaviour throughout the night, consistently towards that of the nycthemeral migration of myctophids. In the southern Pacific Ocean, Juan Fernandez fur seals also fed on myctophids and foraged in waters of similar SST $\left(14.6^{\circ} \mathrm{C}\right.$, Francis et al. 1998) to those in the present study, suggesting that STF may be a predictably productive foraging area for several fur seal species in the Southern Ocean.

Third phase. During this phase, diving activity decreased to half that of the second (feeding) phase, and was associated with an increase in SST, indicating that seals were moving back to Amsterdam Island. Most of the distance travelled occurred during the daytime, while diving activity still occurred during the night. The relatively high diving activity, and long duration of the third phase suggest that most fur seals were still feeding when they were swimming back to Amsterdam Island. This contrasts with Steller sea lions Eumetopias jubatus (Merrick et al. 1994) and northern fur seals (Loughlin et al. 1987) that come back from their foraging ground without any apparent feeding activity.

In winter (June-July 1995), the $14.0^{\circ} \mathrm{C}$ surface isotherm migrated $250 \mathrm{~km}$ north of Amsterdam Island. Interestingly, 2 of 5 seals travelled $420 \mathrm{~km}$ northwards to reach waters of similar SST (up to $15.6^{\circ} \mathrm{C}$ ) as in summer, whereas the 3 others travelled up to $530 \mathrm{~km}$ southwards. Of the 9 seals studied in winter, only the trips of 2 seals were recorded as the TDRs of the 7 remaining seals returned with their memory capacity full. For these 2 seals, there was no consistent pattern in diving activity throughout the trip. One seal was travelling northwards and showed a high diving activity during the first days spent at sea, whereas the second one was travelling southwards and showed a high diving activity during the last days. Fur seals travelling southwards encountered colder waters than in summer. Cooling of sea temperatures may have induced changes either in prey communities encountered or in prey distribution compared to summer, which were compensated for by a change in foraging behaviour.

For seals foraging in waters of similar SST in winter as those in summer, decreasing SST gradient in winter may have induced a decrease in biological activity and a less patchy distribution of resources (Mann \& Lazier 1991). Consequently, the chance of encountering dense patches may be lower in winter than in summer, so that fur seals do not concentrate their diving activity as they do in summer. In summer, most of the feeding activity occurs in the oceanic mixed layer (10 to $20 \mathrm{~m}$, Georges et al. 2000), where biomass and biological activity are known to be accumulated (Mann \& Lazier 1991). However in winter, the oceanic mixed layer is inaccessible to Subantarctic fur seals (Georges et al 2000) while the foraging efficiency in lactating Subantarctic fur seals decreases in winter, compared to earlier seasons (Georges \& Guinet 2000). All these findings support the above hypothesis of a decrease in prey availability in winter for which fur seals try to compensate by increasing their diving effort (Georges et al. 2000). Seasonal changes may also occur in prey communities, and further studies are needed to investigate seasonal diet in Subantarctic fur seals at Amsterdam Island.

\section{Annual comparisons}

Because of low sample sizes during the first trips after parturition and the incomplete records in winter, annual comparisons can only be performed between summers 1996 and 1997.

Foraging trips were longer in February 1996 than in January 1997, which could be related to the increase in foraging trip duration throughout the year observed by Georges \& Guinet (2000). However, the $8 \mathrm{~d}$ increase in foraging trip duration observed in this study was higher than that observed in Georges \& Guinet (2000) (4 d). As the devices used were similar in 1996 and 1997, changes in oceanographic conditions (SST distribution) may have affected foraging trip duration between years. Despite the increase in foraging trip duration, transit time (duration of the first phase) was similar between years ( $3 \mathrm{~d}$ ) and this is consistent with the similar distance between Amsterdam Island and the STF during both years (Table 1). Furthermore, the organisation of the trips was similar in 1996 and 1997 as the second and third (actively feeding) phases corresponded, on average, to 50 and $30 \%$ of the whole trip duration, respectively. Moreover, mean diving activity did not differ over the trips between 1996 and 1997. In other words, longer foraging trips in 1996 were due to longer feeding and return phases than in 1997, and seals spent relatively more time diving during longer foraging trips in February 1996. Interestingly, the surface temperature gradient of the STF was lower in February 1996 than in January 1997 (Table 1). Lower gradients are expected to be associated with lower resources (Mann \& Lazier 1991), but also with changes in prey communities. According to Table 1, the position and the surface temperature gradient of the STF indicate that waters south of Amsterdam Island were relatively warmer over a wider area in 1996 than in 1997. Thus, the area exploited by Subantarctic fur seals in 1996 was likely to be characterised by warm-water prey species, which are less energy-rich than cold- 
water species, probably more abundant in 1997. Further studies are required to investigate annual changes in the diet of Subantarctic fur seals.

Annual changes in surface temperature gradient may affect the distribution and the availability of resources. Interestingly, diving activity increased 6 to 7 times between the first and the second phases in 1996 whereas it increased only 3.5 times in 1997. These differences were due to a lower diving activity during the first phase in 1996 than in 1997 while it remained similar during the feeding phases. Such results suggest that the stronger surface temperature gradient of the STF in 1997 allowed fur seals to reach the southern foraging grounds while substantially diving (feeding). Inversely, the lower diving activity during the first phase in 1996 suggests that fur seals did not encounter exploitable food patches when swimming to the southern foraging areas. Consistently the seal fitted with a direction recorder in 1996 travelled directly to the south-east without any apparent change in behaviour during this period (Fig. 4).

In the present study, seals monitored during the 1997 summer spent on average $10 \mathrm{~d}$ at sea, corresponding to foraging ranges between 20 and $430 \mathrm{~km}$ from Amsterdam Island. During the 1995 winter, foraging trip duration was about $25 \mathrm{~d}$ and foraging range was estimated to be between 410 and $530 \mathrm{~km}$. The consistency in foraging trip duration between a previous study (where seals were unequipped, Georges \& Guinet 2000) and the present study (where seals were fitted with streamlined devices) suggests that the time spent at sea was not affected by the devices. Furthermore, the present study indicates that the increase in foraging trip duration observed over the pup-rearing period (Georges \& Guinet 2000) is related to foraging grounds located further away during winter. Similarly, distance to the foraging grounds has been reported to be an important component of trip duration in lactating northern fur seals (Gentry 1998) and Steller sea lions (Merrick \& Loughlin 1997). Furthermore, in Subantarctic fur seals, maternal foraging efficiency decreased in winter compared to summer (Georges \& Guinet 2000) despite the increase in diving effort (Georges et al. 2000), suggesting that productivity (prey density) declined between summer and winter. Subantarctic fur seals appear to compensate for changes in oceanographic conditions, and thus probably, food availability, by increasing their time spent at sea, their foraging range, and by changing the organisation of their foraging trip, which is consistent with the seasonal migration of the STF and changes in its SST gradient, and thus probably marine resources.

Acknowledgements. We are grateful to the members of the 45th, 46th, 47th and 48th research missions at Amsterdam
Island for their assistance in the field, in particular to Yann Tremblay, Laurent Zimmerman, Jean-Marc Salles, Maxime Aimetti, Laurent Baudchon, André Catala, Sébastien Croix, Dominique Filippi, Piotr Freindorf, Philippe Gendreau, Raphael Hancy, Jean-Phillipe Hussenet, Jean-Christophe Julien, Erwan Kerzreho, Philippe Mansuy, Christian Morino, Pierre Nadeau, Laurent Naudé, Christian Rey, Jean Sciare, Xavier Sevot and Cyril Szakolczaï. Luigi Dall' Antonia helped in tuning the direction recorder. This work was supported financially and logistically by 'Terres Australes et Antarctiques Françaises, TAAF' and 'Institut Français pour la Recherche et la Technologie Polaires, IFRTP'. A Marie Curie fellowship from the European Community (Fourth Framework Programme, Training and Mobility of Researchers, Contract No. ERBFMBICT972614) financed F.B. J.-Y.G. was supported by Smith and 'La Communauté de Villes de l'Agglomération de La Rochelle'.

\section{LITERATURE CITED}

Abrams RW (1985) Environmental determinants of pelagic seabird distribution in the African sector of the Southern Ocean. J Biogeogr 12:473-492

Antonelis GA, Stewart BS, Perryman WF (1990) Foraging characteristics of female northern fur seals (Callorhinus ursinus) and Californina sea lions (Zalophus californianus). Can J Zool 68:150-158

Baba $N$, Kiyota $M$, Yoshida $K$, Loughlin TR, Antonelis GA (1991) Satellite tracking of northern fur seal (Callorhinus ursinus). In: Uchida A, Amlaner CJ (eds) Biotelemetry. XI Proceedings of the 11 th International Symposium of Biotelemetry, Yokohama, Japan. Waseda University Press, Tokyo, p 104-107

Belkin IM, Gordon AL (1996) Southem Ocean fronts from the Greenwich meridian to Tasmania. J Geophys Res 101: 3675-3696

Bonadonna F, Lea MA, Guinet C (2000) Foraging routes of Antarctic fur seal (Arctocephalus gazella) investigated by the concurrent use of satellite tracking and time-depthrecorders. Polar Biol 23:149-159

Bost CA, Georges JY, Guinet C, Cherel Y, Pütz K, Charrassin JB, Handrich Y, Zorn T, Lage J, Le Maho Y (1997) Foraging habitat and food intake of satellite king penguins during the austral summer at Crozet Archipelago. Mar Ecol Prog Ser 150:21-33

Boyd IL (1999) Foraging and provisioning in Antarctic fur seals: interannual variability in time-energy budgets. Behav Ecol 10:198-208

Boyd IL, Ambom T (1991) Diving behaviour in relation to water temperature in the southem elephant seal:foraging implications. Polar Biol 11:259-266

Boyd IL, Lunn NJ, Barton T (1991) Time budgets and foraging characteristics of lactating Antarctic fur seals. J Anim Ecol $60.577-592$

Boyd IL, Arnould JPY, Barton T, Croxall JP (1994) Foraging behaviour of Antarctic fur seals during periods of contrasting prey abundance. J Anim Ecol 63:703-713

Boyd IL, McCafferty DJ, Reid K, Taylor R, Walker TR (1998) Dispersal of male and female Antarctic fur seals (Arctocephalus gazella). Can J Fish Aquat Sci 55:845-852

Costa DP (1993) The secret life of marine mammals, novel tools for studying their behaviour and biology at sea Oceanography 6:120-128

Costa DP, Trillmich F (1988) Mass changes and metabolism during the perinatal fast: a comparison between Antarctic (Arctocephalus gazella) and Galapagos fur seals (Arctocephalus galapagoensis). Physiol Zool 61(2):160-169 
Dall'Antonia L, Dall'Antonia P, Benvenuti S, Ioale P. Massa $B$, Bonadonna $F$ (1995) The homing behaviour of Cory's shearwaters (Calonectris diomedea) studied by means of a direction recorder. J Exp Biol 198:359-362

Deacon GER (1982) Physical and biological zonation in the Southern Ocean. Deep-Sea Res 29:1-15

El Sayed SZ (1988) Seasonal and interannual variabilities in Antarctic phytoplankton with reference to krill distribution. In: Sahrhage D (ed) Antarctic Ocean and resources variability. Springer-Verlag, Berlin, p 102-119

Figueroa AL (1994) Early lactation and attendance behavior of the Guadalupe fur seal females (Arctocephalus townsendi). MSc thesis, University of California, Santa Cruz, CA

Francis J, Boness D, Ochoa-Acuna H (1998) A protracted foraging and attendance cycle in female Juan Fernandez fur seals. Mar Mamm Science 14:552-574

Gentry RL (1998) The behavior and ecology of the northern fur seal. Princeton University Press, Princeton, NJ

Gentry RL, Costa DP, Croxall JP, David JHM, Davis RW, Kooyman GL, Majluf P, McCann TS, Trillmich F (1986) Synthesis and conclusions. In: Gentry RL, Kooyman GL (eds) Maternal strategies on land and at sea. Princeton University Press, Princeton, NJ, p 220-265

Georges JY, Guinet C (2000) Maternal care in the Subantarctic fur seals on Amsterdam Island. Ecology 81:295-308

Georges JY, Guinet C (in press) Early mortality and perinatal growth in the Subantarctic fur seals Arctocephalus tropicalis on Amsterdam Island. J Zool

Georges JY, Tremblay Y, Guinet C (2000) Seasonal diving behaviour in lactating Subantarctic fur seals on Amsterdam Island. Polar Biol 23:59-69

Guinet C. Jouventin P. Georges JY (1994) Long term population changes of fur seals Arctocephalus gazella and Arctocephalus tropicalis on Subantarctic (Crozet) and subtropical (St Paul and Amsterdam) islands and their possible relationship to El Niño Southern Oscillation. Antarct Sci $6(4): 473-478$

Guinet C, Koudil M, Bost CA, Durbec JP, Georges JY, Mouchot MC, Jouventin P (1997) Foraging behaviour of satellite-tracked king penguins in relation to sea-surface temperatures obtained by satellite telemetry at Crozet Archipelago, a study during three austral summers. Mar Ecol Prog Ser 150:11-20

Harcourt RG, Schulman AM, Davis LS, Trillmich F (1994) Summer foraging by lactating female New Zealand fur seals (Arctocephalus forsteri) off Otago Peninsula. New Zealand. Can J Zool 73:678-690

Hindell MA, Burton HR, Slip DJ (1991) Foraging areas of southern elephant seals, Mirounga leonina, as inferred from water temperature data. Aust J Mar Freshw Res 42:115-128

Horning $M$, Trillmich $F$ (1997) Ontogeny of diving behaviour in the Galapagos fur seal. Behaviour 134:1211-1257

Hunt GL, Schneider DC (1987) Scale-dependent processes in the physical and biological environment of marine birds. In: Croxall JP (ed) Seabirds: feeding, ecology and role in marine environment. Cambridge University Press, Cambridge, $p 7-41$

Jaquet $N$, Whitehead $H$ (1996) Scale-dependent correlation of sperm whale distribution with environmental features and productivity in the South Pacific. Mar Ecol Prog Ser 153:1-9

Klages NTW, Bester MN (1998) Fish prey of fur seals Arctocephalus spp. at subantarctic Marion Island. Mar Biol 131. 559-566

Koubbi P (1993) Influence of the frontal zones on ichthyoplankton and mesopelagic fish assemblages in the Crozet Basin (Indian sector of the Southern Ocean). Polar Biol 13:557-564
Laubscher RK, Perissinotto R, McQuaid CD (1993) Phytoplankton production and biomass at frontal zones in the Atlantic sector of the Southern Ocean. Polar Biol 13:47i-481

Loughin TR, Bengtson JL, Merrick RL (1987) Characteristics of feeding trips of female northern fur seals. Can J Zool 65 . 2079-2084

Lutjeharms JRE (1985) Location of frontal systems between Africa and Antarctica: some preliminary results. Deep-Sea Res 32:1499-1509

Lutjeharms JRE, Valentine HR (1984) Southern Ocean thermal fronts south of Africa. Deep-Sea Res 31:1461-1475

Lutjeharms JRE, Walters NM, Allanson BR (1985) Oceanic frontal systems and biological enhancement. In: Siegfried WR, Condy PR, Laws RM (eds) Antarctic nutrient cycles and food webs. Springer-Verlag, Berlin, p 1.1-21

Machida S (1974) Sufface temperature field in the Crozet and Kerguelen whaling grounds. Sci Rep Whales Res Inst 26: 271-287

Mann KH, Lazier JRN (1991) Dynamics of marine ecosystems, biological-physical interactions in the oceans. Blackwell Scientific Publications, Boston

MCConnell BJ, Chambers C, Fedak MA (1992) Foraging ecology of southern elephant seals in relation to the bathymetry and productivity of the Southern Ocean. Antarct Sci 4: 393-398

Mehlum F, Nordlund N, Isaksen K (1998) The importance of the 'polar front' as a foraging habitat for guillemots Uria spp. breeding at Bjornoya, Barents Sea. J Mar Syst 14 $27-43$

Merrick RL, Loughlin TR (1997) Foraging behaviour of adult female and young-of-the-year. Steller sea lions in Alaskan waters. Can J Zool 75:776-786

Merrick RL, Loughlin TR, Antonelis GA, Hill R (1994) Use of satellite-linked telemetry to study Steller sea lion and northern fur seal foraging. Polar Res 13:105-114

Neu NH, Byers CR, Peek JR (1974) A technic for analysis of utilization-availability data. J Wildl Agent 38:541-545

Pakhomov EA, Froneman PW (1999) The Prince Edward Islands pelagic ecosystem, south Indian Ocean: a review of achievements, 1976-1990. J Mar Sci 18:355-367

Pakhomov EA, Perissinotto R, McQuaid CD (1994) The comparative structure of the macrozooplankton/micronekton communities of the subtropical and antarctic polar fronts. Mar Ecol Prog Ser 111:155-169

Reynolds RW, Smith TM (1994) Improved global sea-surface temperature analysis. J Clim 7:929-948

Service Argos (1984) Location and data collection system user's guide. Service Argos, Toulouse

Sokal RR, Rohlf FJ (1981) Biometry. Freeman, New York

Tollu B (1974) L'otarie de l'île Amsterdam Arctocephalus tropicalis tropicalis (Gray 1872). PhD thesis, Université de Paris VII

Tynan CT (1998) Ecological importance of the Southern Boundary of the Antarctic Circumpolar Current. Nature 392:708-710

Weimerskirch H, Doncaster CP, Cuenot-Chaillet F (1994) Pelagic seabirds and the marine environment: foraging patterns of wandering albatrosses in relation to prey availability and distribution. Proc R Soc Lond B 255:91-97

Weimerskirch $\mathrm{H}$, Wilson RP, Guinet C, Koudil M (1995) The use of seabirds to monitor sea-surface temperatures and to validate satellite remote-sensing measurements in the Southern Ocean. Mar Ecol Prog Ser 126:299-303

Weimerskirch $\mathrm{H}$. Wilson RP, Lys P (1997) Activity pattern of foraging in the wandering albatross: a marine predator with two modes of prey searching. Mar Ecol Prog Ser 151. $245-254$ 